\title{
ASTRONOMY EDUCATION AND DEVELOPMENT
}

ENSEIGNEMENT DE L'ASTRONOMIE

\author{
PRESIDENT \\ VICE-PRESIDENT \\ ORGANIZING COMMITTEE
}

\author{
Jay M. Pasachoff \\ Barrie W. Jones \\ John B. Hearnshaw, Michèle Gerbaldi, \\ Lars Lindberg Christensen, \\ Charles R. Tolbert, John R. Percy
}

\section{COMMISSION 46 PROGRAM GROUPS}

Div. XII / Commission 46 PG

Div. XII / Commission 46 PG

Div. XII / Commission 46 PG

Div. XII / Commission 46 PG

Div. XII / Commission 46 PG

Div. XII / Commission 46 PG

Div. XII / Commission 46 PG

Div. XII / Commission 46 PG

Div. XII / Commission 46 PG
World-Wide Development of Astronomy

Teaching Astronomy Development

International Schools for Young

Astronomers

Exchange of Astronomers

National Liaisons on Astronomy

Education

Collaborative Programs

Commission Newsletter

Public Information at the Times of Solar Eclipses

Exchange of Books, Journals, Materials

\section{TRIENNIAL REPORT 2003-2006}

\section{Introduction}

The International Astronomical Union (IAU) was founded in 1922 to "promote and safeguard astronomy ... and to develop it through international co-operation". The IAU is funded through its National Members. Almost all of the funds supplied from the dues are used for the development of astronomy.

One of the 40 IAU "Commissions" is Commission 46, formerly called The Teaching of Astronomy and more recently, at the 2000 General Assembly, renamed Astronomy Education and Development. It is the only Commission that deals exclusively with astronomy education; a previous Commission 38 (Exchange of Astronomers), which allocated travel grants to astronomers who need them, and a Working Group on the Worldwide Development of Astronomy, have been absorbed by Commission 46 .

The Commission's mandate is "to further the development and improvement of astronomy education at all levels, throughout the world".

In general, the Commission works with other scientific and educational organizations to promote astronomy education and development; through the National Liaisons to the Commission, it promotes astronomy education in the countries that adhere to the IAU; and it encourages all programs and projects that can help to fulfill its mandate. 


\section{Activities}

The Commission holds business sessions at each IAU General Assembly. Within the format of the IAU General Assemblies, the Commission organizes or co-sponsors major sessions on education-related topics, such as a Special Session held at the 2003 General Assembly in Sydney, Australia, on which a book was published: Teaching and Learning Astronomy: Effective Strategies for Educators Worldwide, edited by John R. Percy and Jay M. Pasachoff (Cambridge: CUP, 2005).

The Commission has also organized two major conferences on astronomy education - in the USA in 1988, and in the UK in 1996:

- Jay M. Pasachoff \& John R. Percy, eds., 1990, The Teaching of Astronomy, Proc. IAU Colloquium No. 105 (Cambridge: CUP).

- L. Gouguenheim, D. McNally, \& J. R. Percy, eds., 1998, New Trends in Astronomy Teaching, Proc. IAU Colloquium No. 162 (Cambridge: CUP).

- John Percy, ed., 1996, Astronomy Education: Current Developments, Future Coordination, ASP-CS 89 (San Francisco: ASP).

For three decades, the Commission has sponsored one-day workshops for local school teachers, as part of every IAU General Assembly, and as part of several IAU regional meetings. Immediately after the conference that is described in the forthcoming book, a very successful teachers' workshop was held in Sydney, organized by Nicholas Lomb, Sydney Observatory. Because of language difficulties, only local astronomers organized a teachers' conference after the Prague General Assembly.

Until recently, Commission 46 was concerned primarily with tertiary (university-level) education and beyond, but several of its activities have an impact on school-level and public education.

Commission 46 was involved in a series of sessions and a Special Session for the 14-25 August 2006 IAU General Assembly. Special Session 2 on Innovation in Teaching/Learning Astronomy was organized by Rosa M. Ros and Jay M. Pasachoff. Special Session 5 on Astronomy Education in the Developing World was organized by John Hearnshaw. Both have been published in the Highlights of Astronomy, Volume 14 (Ed. Karel A. van der Hucht, 2007, CUP).

\section{Program Groups of Commission 46}

\subsection{PG for the Worldwide Development of Astronomy}

The role of this PG is to visit countries with some astronomical expertise at tertiary (i.e., post high school) level, which are probably not IAU member states, but which would welcome some development of their capabilities in teaching and/or research in astronomy. For example, as a result of a visit last year, Mongolia joined the IAU at the IAU XXVI GA in Prague, and has received advice on broadening their astronomy programs.

OC: John B. Hearnshaw (chair), Athem Alsabti, Alan Batten, Julietta Fierro, Richard Gray, Mary Kay Hemenway, Yoshihide Kozai, Hugo Levato, Peter Martinez, Don Wentzel, Jay White, and Jayant Narliker.

\section{2. $P G$ for Teaching for Astronomy Development}

TAD is intended to assist a country with currently little astronomy which wants to enhance its astronomy education significantly. TAD operates on the basis of a proposal from a professional astronomy organization or on the basis of a contract between the IAU and an academic institution, usually a university.

The capabilities of the TAD program are limited to assistance with university-level activities, such as

(a) the creation of university-level astronomy/astrophysics courses and the faculty training and equipment associated with the development and first offering of such courses

(b) a basic, largely educationally oriented research capability for faculty and students

(c) travel (i.e. transportation) costs of foreign visiting lecturers and of students invited for study at foreign universities, and

$(d)$ professional preparations needed as a prerequisite for plans to offer astronomy in schools and for the public. TAD can provide advice about education of school teachers, but not financial support. The training of school teachers and the actual performance of school teaching and public outreach is considered to be part of the national resources. 
OC: Jay White, Don Wentzel, Armando Arellano Ferro, Khalil Chamcham, David Clarke, Nguyen Dinh Huan, Nidia Morrell, Derek McNally, John Percy, Maria Cristina Pineda de Carias, and Nguyen Quang Rieu.

\subsection{PG for International Schools for Young Astronomers}

ISYA seeks the participation of young astronomers mainly, but not exclusively, from astronomically developing countries. Participants should generally have finished first-degree studies. ISYA seeks to broaden the participants perspective on astronomy by lectures from an international faculty on selected topics of astronomy, seminars, practical exercises and observations, and exchange of experiences. The most recent ISYAs were in Morocco in 2004 and in Puebla, Mexico in 2005. The next ISYA will be in Malaysia in 2007 (March-April).

OC: Michèle Gerbaldi, Ed Guinan.

\section{4. $P G$ for Exchange of Astronomers}

The PG makes travel grants to qualified individuals in order to enable them to visit institutions abroad where they may interact with the intellectual life and participate in the research of the host institution. It is the objective of the program that astronomy in the home country be enriched after the applicant returns. The PG publishes, both on the IAU web site and in IAU Information Bulletins, all the information needed to apply for a grant under the IAU Exchange of Astronomers program.

Membership 2003-2006: Charles Tolbert (chair), John Percy (vice-chair). The group administers the IAU's program of grants for exchange of astronomers, which enables qualified applicants (usually young astronomers from astronomically-developing countries) to visit institutions abroad for periods of three months or greater.

During the period 2003-2006, 15 grants were awarded, for a total of $\$$ US 20,975. Grantees came from 10 different countries, and visited institutions in 9 different countries.

OC: Charles Tolbert, and John Percy.

\subsection{PG for National Liaisons on Astronomy Education}

The main duty of the National Liaison on Astronomy Education is (a) to write the triennial national report, to make it a valuable resource for countries wishing to enhance their astronomy education, and (b) to transmit to the educators of his/her own country the insights that they might glean from the reports and conferences.

OC: Barrie W. Jones.

\subsection{PG for Collaborative Programs}

This Program Group works on activities co-sponsored by UNESCO, COSPAR, UN, ICSU, etc., and carries out interactions with other international organizations. It will be our main link with the 2009 International Year of Astronomy.

OC: Syuzo Isobe, Jonannes Anderson, Christopher Corbally, David Crawford, Julieta Fierro, Hans Haubold, Seigbert Raither, Dale Smith, James C White II, P Willekens, and Peter Willmore.

\section{7. $P G$ for Commission Newsletter}

The Newsletter is published twice a year, and is available (including back issues) on the IAU web site.

OC: Barrie W. Jones, and Tracey Moore.

\subsection{PG for Public Information at the Times of Solar Eclipses}

Timely advice for countries that will experience a solar eclipse, see <http://www .eclipses . info> in order to consult with local astronomers and with newspapers.

For the latest transit of Venus, see <http://www. transitof venus.info>.

OC: Jay Pasachoff, Ralph Chou, and Julieta Fierro. 
3.9. $P G$ for the Interchange of Books, Journals, and Materials

We are re-studying the role of this program group in the context of new electronic document possibilities, but we can still link people needing written material with those for whom the material is surplus.

OC: John Percy

Jay M. Pasachoff president of the Commission 